NBER WORKING PAPER SERIES

\title{
REFUGEES, ASYLUM SEEKERS AND POLICY IN EUROPE
}

\author{
Timothy J. Hatton \\ Jeffrey G. Williamson \\ Working Paper 10680 \\ http://www.nber.org/papers/w10680 \\ NATIONAL BUREAU OF ECONOMIC RESEARCH \\ 1050 Massachusetts Avenue \\ Cambridge, MA 02138 \\ August 2004
}

This paper draws heavily on our own recent work (Hatton and Williamson 2003; Hatton 2004) and on our ongoing book World Mass Migration: Two Centuries of Policy and Performance. We are grateful to the organizers of the Kiel Week Conference on Labor Mobility and the World Economy (June 21-22, 2004), where an earlier version of this paper was presented and to the participants at the conference for their comments. Hatton acknowledges support through a British Academy Research Readership and Williamson acknowledges financial support from the National Science Foundation SES-0001363. The views expressed herein are those of the author(s) and not necessarily those of the National Bureau of Economic Research.

C2004 by Timothy J. Hatton and Jeffrey G. Williamson. All rights reserved. Short sections of text, not to exceed two paragraphs, may be quoted without explicit permission provided that full credit, including $(\subset$ notice, is given to the source. 
Refugees, Asylum Seekers and Policy in Europe

Timothy J. Hatton and Jeffrey G. Williamson

NBER Working Paper No. 10680

August 2004

JEL No. F22, J1, O15

\section{ABSTRACT}

The number of refugees worldwide is now 12 million, up from 3 million in the early 1970s. And the number seeking asylum in the developed world increased tenfold, from about 50,000 per annum to half a million over the same period. Governments and international agencies have grappled with the twin problems of providing adequate humanitarian assistance in the Third World and avoiding floods of unwanted asylum seekers arriving on the doorsteps of the First World. This is an issue that is long on rhetoric, as newspaper reports testify, but surprisingly short on economic analysis. This paper draws on the recent literature, and ongoing research, to address a series of questions that are relevant to the debate. First, we examine the causes of refugee displacements and asylum flows, focusing on the effects of conflict, political upheaval and economic incentives to migrate. Second, we examine the evolution of policies towards asylum seekers and the effects of those policies, particularly in Europe. Finally, we ask whether greater international coordination could produce better outcomes for refugee-receiving countries and for the refugees themselves.

Timothy J. Hatton

School of Economics

Australian National University

Canberra, ACT 0200

Australia

tim.hatton@anu.edu.au

Jeffrey G. Williamson

Department of Economics

Harvard University

Cambridge, MA 02138

and NBER

jwilliam@fas.harvard.edu 


\section{Introduction}

The worldwide number of refugees has increased by a factor of four since the early 1970 s -- from about 3 to 12 million. And the number seeking asylum in developed countries has increased by a factor of about ten over the same period - from about 50,000 per annum in the early 1970 s to half a million in 2001 . This is seen by many as a crisis of growing proportions, and for two reasons. First, there is the humanitarian issue. Most refugees are displaced across borders in the Third World, suffering oppression, poverty and disease. With each new humanitarian crisis comes new criticism of the unwillingness or inability of governments and international agencies to act more decisively to solve the refugee problem, or at least to better ameliorate the condition of the refugees. Second, the arrival of increasing numbers of asylum seekers on the doorsteps of the First World has led to fierce political debate about asylum policies, often fuelled by parties of the far right. Despite protest from humanitarian groups, governments have responded to the rising political temperature with a range of measures aimed at deterring asylum applications.

This paper draws on the recent literature and some of our own analysis to address a series of questions that are relevant to these debates. First, what are the causes of refugee displacement? Are they mainly political or economic? Second, how far can wars, political crises and economic conditions explain the apparently inexorable rise in the number of asylum seekers, particularly in Europe, but in the rest of the OECD as well? Third, how has asylum policy evolved in Europe and has it been effective in deterring asylum seekers, or has it instead simply deflected them elsewhere? Fourth, could greater international cooperation lead to outcomes that are better for refugee-receiving countries as well as for the refugees themselves? And finally, are there better policies? 


\section{Refugees and Asylum Seekers}

Refugee and asylum seeker figures come from estimates compiled by the United Nations High Commission for Refugees (UNHCR). The definition of a refugee is derived from the 1951 Geneva Convention on Refugees, namely someone who, owing to a wellfounded fear of persecution, is outside his or her country of normal residence and who is unable or unwilling to return to it. The UNHCR estimates plotted in Figure 1 show a dramatic increase from the early 1970s to a peak of nearly 18 million in 1992, before falling by a third to 12 million in $2001 .{ }^{1}$ Two further points are worth noting about these refugee totals. First, they exclude an additional five million who in 2001 were internally displaced and living in refugee-like situations but who were not classified as refugees because they were not outside their country of origin. Second, these refugee stock figures undergo considerable turbulence and turnover. When the refugee stock fell by 5.8 million between 1992 and 2001, there were 10.7 million new refugee arrivals and 16.5 million exits.

The overwhelming majority of these refugees are located in the Third World, close to their country of origin. As Table 1 shows, there is a very strong correlation between the number of refugees that originated in a region and the number who are located within that region. In 200149 percent of refugees originated somewhere in Asia or the Middle East and 46 percent were located there, while 30 percent originated in Africa and 27 percent were located there. Eastern Europe was the source of 11 percent of the refugees and host to 6 percent, some of whom were from outside the region. Western Europe hosted 1.7 million refugees from other regions in 2001 (14 percent of the worldwide total) while a further 646,000 (5 percent) were located in North America. As Figure 1 shows, the number of refugees in Europe rose sharply between the late 1980s and the early 1990s while the number in North America declined. These trends are consistent with the rapid growth in the number of asylum seekers arriving in Europe.

\footnotetext{
${ }^{1}$ Estimates of the total number of refugees differ. The United States Committee for Refugees (2003, p. 3) provides a figure of 14.9 million for 2001, nearly 3 million higher than the UNHCR estimate. Some of the definitional issues in constructing these totals are discussed in UNHCR (2002, pp. 71-5) and Crisp (1999). Nevertheless, while estimates of the total differ, the profile of change over time is essentially the same.
} 
Figure 2 plots the total number of new asylum applications lodged in 37 industrialized countries (a flow rather than a stock) by region of asylum. ${ }^{2}$ It documents an enormous surge from about 150,000 per annum in the early 1980s to a peak of more than 850,000 in 1992 , falling sharply to 380,000 in 1997 before rising again more recently. It also confirms once again that the bulk claimed asylum in Europe, principally in the 15 countries of the European Union (pre-enlargement). The EU accounted for 68 percent of all applications over the 20-year period, and North America accounted for most of the remainder. The sharp spike in the early 1990s (Figure 3) was accounted for by applications from Eastern Europe following the disintegration of the Soviet Union and the conflicts that followed the breakup of the former Yugoslavia. Still, there is evidence of an underlying upward trend, not only in applications from Europe, but also from Africa and Asia.

The left hand panel of Table 2 reports the total number of applications from each of the top 20 source countries by decade. Not surprisingly Eastern Europe is well represented with large numbers arriving from Yugoslavia, Romania, Bosnia and the Russian Federation, as is the Middle East with large numbers from Turkey, Iraq, Iran and Afghanistan. Asia is also well represented by China, India, Pakistan and Sri Lanka. While there is a clear correspondence between the number of refugees and the number of asylum seekers, some of the poorest countries (such as Angola, Rwanda and Ethiopia/Eritrea) did not generate as many asylum seekers as might have been expected given the scale of the conflicts. Indeed, most African refugees do not get much further than a neighboring country, if they manage to leave at all. It is also notable that most of the countries that generated large numbers of asylum seekers in 1992-2001 also generated significant numbers in the previous decade. As we shall see, this historical persistence is an important feature of asylum flows, especially to Europe.

The right-hand panel of Table 2 documents the top 20 countries in the developed world that receive asylum applications. Germany tops the list with a massive 1.6 million applications in 1992-2001, followed by the United States and the United Kingdom. Nine other EU countries also appear on the list, some of which have very large per capita rates

\footnotetext{
${ }^{2}$ These data are collected by the UNHCR, mainly from national governments. They are typically first instance claims and they represent the number of applications rather than the number of individuals. On
} 
(Belgium, Netherlands, Sweden, Switzerland). More notable still is the appearance on the list of Turkey, the Czech Republic, Hungary and Poland, countries that were major sources of asylum seekers in the 1980s. Those countries might have become more attractive havens in the post-Soviet period, but it may also reflect the increasing difficulty of entering Western Europe. While most destination countries experienced an increase in the number of applications between the 1980s and the 1990s, the growth in those numbers varied widely. In Western Europe, large percentage increases occurred in the UK, the Netherlands, Belgium and Ireland (from a base close to zero), while modest increases or small declines occurred in France, Switzerland, Sweden and Austria. We shall examine the pattern of asylum claims in European destinations later, but first we turn to refugee origins.

\section{The Causes of Refugee Flights}

What causes refugees to flee their home country and seek sanctuary abroad? Perhaps the answer seems too obvious to warrant further discussion. For major refugee displacements such as those in Rwanda, Somalia, El Salvador or Afghanistan the associated wars and conflicts are well known. Quantitative analyses typically focus on some measure of the incidence and intensity of conflict within the country as the main explanation. Table 3 offers an example using data from sub-Saharan Africa. Here the dependent variable is the total stock of refugees from a given country per thousand of the source country population, across 41 African countries annually from 1987 to 1992. There are 142 cases in this sample where no refugees are observed and another 104 with positive numbers of refugees. We therefore use tobit analysis. The explanatory variables exploit a variety of measures of violence and political instability from data assembled by Robert Bates (see Hatton and Williamson 2003).

Given that most of the variables in Table 3 are dummies, the coefficients can be read as the number of refugees per thousand created as a result of the violence event in question. Coups d'etat typically create an efflux of 35 per thousand while government crises generate about 18 per thousand, but these effects are only on the borderline of significance. The incidence of guerilla warfare yields a more significant coefficient and 
the effect generates 25 refugees per thousand of the population. However, civil war is the most important variable generating refugees - about 35 refugees per thousand - while each military death in civil war (a proxy for the intensity of the war) generates another 35 refugees per thousand. Despite the strength of the civil war effects, the explanatory power of the regression as a whole is still rather low, as reflected in the pseudo $\mathrm{R}^{2}$. This is because of the enormous heterogeneity in the size and intensity of the conflicts, and their refugee generating effects, none of which is adequately reflected by these crude explanatory variables.

Perhaps these results are unsurprising, but they raise a number of issues. First, if as some believe, refugee flights are determined by economic and demographic forces as well as by politics and violence, then these variables should also play a role. Indeed, some studies do find such effects, but they are generally weak in comparison to politics and violence. The African data also support that view. When variables such as real wage rates and the share of population aged 15-29 were added, they proved to be insignificant. Should we therefore conclude that economic and demographic factors play no role? Not necessarily, since war and violence are highly correlated with poor economic conditions and large young adult populations. And once the conflicts cease, the economy rapidly bounces back, so that their effects on refugees may not persist. ${ }^{3}$

Second, the regression analysis is applied to the stock of refugees, rather than the flow in to and out of refugee status. If refugees remain displaced for a number of years, even after the end of the conflict or crisis, then lagged values should also matter. However, when the regression in Table 3 is re-estimated with the addition of lagged explanatory variables one and two years, the coefficients were not significant, suggesting that persistence is not important. This contrasts with the findings of some other studies where lags are found to matter (Schmeidl 1997; Azam and Hoeffler 2000). There are two possible explanations for our conflicting result. One is that the dynamics cannot be isolated in a short panel where most of the variance is in the cross section. The other is

\footnotetext{
${ }^{3}$ Collier (1999) finds that the economies of war-ravaged states grow at 6 percent per year in the five years following the outbreak of peace. Pottenbaum and Kanbur (2001) find that the post-war bounce back in a range of socioeconomic indicators is significantly greater for low-income economies that for middle income economies. They attribute this to the fact that the poorest countries have little infrastructure that can be destroyed during a conflict and they can therefore return to pre-existing socioeconomic levels relatively quickly.
} 
that most refugee migrations in Africa occur just across borders; they are temporary and quickly reversed. Thus, of the14.2 million voluntary repatriations in 1992-2001, 8.3 million of them were in Africa.

It is worth dwelling on the second point for what follows later. Most of the refugee displacements occur when war breaks out or when there is a sudden rise in its intensity. Thereafter the flood subsides and the stock of refugees rises more gently. When the war or crisis abates, repatriation takes place, often quickly and on a scale that resembles that of the original displacement. This is particularly true in Africa where refugees are often displaced to camps just across the border in which conditions are worse even than those in the refugee's war ravaged homeland. In addition, refugees have in Africa sometimes been pushed back over the border by unwelcoming governments and hostile host populations (Rogge 1994). This response is less likely where the war is protracted and the refugees have assimilated into the host society. It is also less likely when refugees have gained asylum in a country where living standards are an order of magnitude higher than at home. This latter fact helps to explain the strong persistence of refugees in Europe that was observed in Figure 1. It can even be observed within Africa where those finding sanctuary in the Republic of South Africa have been less eager to return. ${ }^{4}$

\section{Has the World Become a More Violent and Dangerous Place?}

If war, violence and political oppression are the fundamental causes that create refugees, then the refugee trends observed in Figure 1 and of asylum applications observed in Figures 2 and 3 should be explained largely by trends in war, violence and persecution. The sources of 'well founded fear of persecution' may, of course, take many forms that are not easy to quantify. Even if we consider wars alone, how do we combine the incidence, intensity and the scale of wars in a way that captures the potential for generating refugees?

\footnotetext{
${ }^{4}$ A 1994 survey of Mozambican refugees indicated that the majority did not want to repatriate. A UNHCR fact finding mission showed that many of these Mozambicans whose families had joined them in the homelands were working on farms and in mines or were otherwise integrated and did not wish to return (Dolan 1999, p. 90).
} 
One index of worldwide conflict is plotted in Figure 4. Each episode of conflict is given a score ranging from one to seven that reflects the scale of the conflict and the overall societal impact (Marshall 2002). A score of one denotes 'sporadic or expressive political violence'-effectively, low level violence by small militant groups. A score of seven denotes 'pervasive warfare'-full-scale war that consumes the entire society. The total conflict index, which adds together all wars, followed an upward trend from 1965 until the late 1980s, a trend that dates back to the 1940s. Contrary to widespread belief, the cold war evinced a secular increase in violence, often associated with proxy wars, independence struggles, and post-colonial civil wars. These escalating levels of violence reached a peak between 1984 and 1992 and have since declined to levels similar to those of the early 1970s. The independence wars of the 1960s and 1970s gave way in the 1980s to inter-country wars, often involving newly independent states. While inter-country wars declined after the late 1980s, civil wars, which account for the bulk of worldwide violence, continued to rise until the early 1990s. These local conflicts often reflect longstanding ethno-political tensions, such as in the former Yugoslavia, that were unleashed by the ending of the cold war.

These patterns bear a fairly close resemblance to those observed in the total stock of refugees and in the flows of asylum seekers. The outbreak of new conflicts declined in the 1990s and the number of conflicts that were either contained or settled increased (Gurr, Marshall and Khosla 2000), However, while the level of conflict fell in the 1990s back to that of the 1970s, the number of refugees and asylum seekers has not returned to its former level. This may reflect an increase in the ability of refugees to escape conflict. On the other hand, the number of refugees generated per conflict may have increased over time as a result of the growth of population at risk and, more importantly, due to greater access to weapons and to advances in weapons technology (Weiner 1997).

A further possibility is that refugee flights have increasingly been generated by causes other than full-scale war. Repressive political regimes, while not engaged in outright war, might nevertheless brutalize or persecute their populations. Measures of human rights abuse are correlated with lack of democracy and/or civil rights, and not only where there are wars and military regimes (Poe et al.1999). One human rights measure is the Freedom House index, which scores the degree of political rights and of 
civil liberties on a scale of one to seven. The index is plotted in Figure 5 where lower numbers represent lower levels of human rights abuse and higher levels of freedom. They show a general increase in civil rights and political freedom with sharp improvements since the late 1980s.

These trends are also reflected in the evolution of political regimes. The percentage of all governments that were autocracies fell gradually from the 1970s and more sharply after the collapse of the Soviet Union and the ending of the cold war (Marshall 1999). Although the number and share of countries under democratic government increased, the greatest rise was - almost by definition -- in the transitional regimes. The evidence suggests that transitional regimes are almost as prone to conflict as autocracies, but it may be easier to escape a chaotic transitional regime than an autocratic police state. That would be consistent with the experience of Eastern Europe after 1989, which accounts for most of the recent increase in the number of states that are labeled transitional. But while states that are not autocratic may be easier to flee, there may also be less reason to do so.

\section{From Refugees to Asylum Seekers in the West}

As we have seen, the total number of refugees rose strongly until 1992 and then fell back while the flow of asylum seekers followed the same pattern but with a steeper increase. This suggests that refugees (or those who claim to be refugees) have over time moved farther away from home conflicts and rights abuse and closer to the developed world, particularly Europe. Very few who claimed asylum did so in the developed world before the 1970s. In 1980-2, the ratio of annual asylum claims to the world-wide stock of refugees was 1.7 percent; by 1999-2001 it had risen to 4.8 percent. So how and why do those displaced by conflicts in the Third World become asylum seekers in the First World?

While some manage to escape directly to Europe or America, costs and increasingly stringent visa requirements have made direct escape difficult. For most refugees, the first and only step is to escape over the border to a neighboring country. Poverty, disease, and risk of violence in refugee camps or shanty towns are among the reasons that so many return home as soon as war ends. Added to this, few of these 
neighboring countries offer the security of refugee status since most are not signatories of the Geneva Convention. Often only temporary visas are given, with limited rights to move outside the camps, to gain employment and to resettle into the host community. While these are good reasons to return home if circumstances permit, they are equally good reasons for onward migration in the hope of better conditions further afield. Thus, although refugee displacements are almost always due to conflict and little else, economic factors play a much greater role in determining the numbers that emerge as asylum seekers in the West and the specific countries to which they apply-an issue that is explored further below.

For some refugees, the escape over the border to a neighboring country is the start of a much longer trip. But it is not simply a matter of applying for asylum at the embassy or consulate of the country of choice upon arrival in some transit country, since most western nations do not admit asylum claims that are lodged outside their borders. Often the only prospect of gaining refugee status is through the refugee status determination procedure offered in the refugee camps or settlements by the UNHCR or even more indirectly through the fieldwork organizations of other NGOs. But the quota for direct resettlement in third countries is small—less than 100,000 per year worldwide - and it has become even more restricted after September 11, 2001. Hence, many potential asylum seekers bypass this process. As one recent report on conditions in East Africa and the Middle East puts it:

Relatively large numbers of people, many in need of international protection and with valid asylum claims, choose not to avail themselves of the UNHCR's refugee determination procedures in the Middle East. Many fear making themselves known to the authorities out of concern of being detained pending refugee status determination and being treated like criminals by local police or security officials. Would be asylum seekers also know that generally only a fraction of asylum applications are granted. Concerned that the determination procedures are lengthy-lasting several months to several years in some countries - that they are unlikely to receive adequate social and economic assistance either from the host government or the UNHCR, and that they may have a better chance of getting to the West if they remain outside the official system, asylum seekers often turn to the services of smuggling organizations (ECRE and USCR, 2001, p. 13).

For many, this means clandestine travel, often across many borders and using many transport modes to reach the chosen destination. Routes into the EU include: from the north, through Russia and the Baltic; from the east, through Hungary, Poland or the Czech and Slovak Republics, stretching back through to the Ukraine; or from the south, either directly from North Africa (the 'blue route') or via Turkey and the Balkans. 
Although hard data are scarce, estimates suggest that more than half of those claiming asylum in countries like Germany, France, the UK and the Netherlands are smuggled in (Morrison and Crosland 2001, p. 17). Estimates for the mid-1990s also suggest that the median payment to traffickers on European inward routes was around $\$ 4000$ to $\$ 5000$ the longer the route, the higher the cost (International Organisation for Migration 2000, p. 94). Thus, it "is the poorest and most marginalized populations around the world that are least able to pay the price to enjoy asylum in Europe" (Morrison and Crosland 2001, p. 21).

Surveys of asylum seekers in Europe show that the degree of deliberation in the choice of route and destination depends on how sudden and unexpected was the departure and how limited were the individual's resources. Where there are choices, asylum seekers tend to gravitate to countries where friends and relatives have preceded them and along routes followed by other asylum seekers from the same source. Factors such as language or other cultural affinities matter too, as do perceptions of economic and social conditions at the destination. ${ }^{5}$ For those who are smuggled in, the destination may be determined by the smugglers and sometimes the journey may end in a transit country rather than at the intended destination.

While a small number of refugees have arrived through organized programs the vast majority are 'spontaneous arrivals' who apply for asylum after having entered the country or at the border. Once having lodged a claim, the applicants must then wait for it to be adjudicated, a process that can take a long time. In the late 1990s, median processing times in the EU were about six months, although these durations have since fallen as processing has been speeded up. But, for a significant minority, the process can drag on for years, especially when there are appeals. At the end of this process, some are granted full refugee status under the Convention while some who are not recognized are nevertheless given residency on humanitarian grounds (often with more restricted rights). The proportion who are successful has declined over the last 20 years. Among applications to 37 industrialized countries, the share of adjudications that resulted in Convention status fell from 50 to 20 percent between 1982 and 2001 while share

\footnotetext{
${ }^{5}$ See for example Böcker and Havinga (1997), Khoser and Pinkerton (2001) and Robinson and Segrott (2002).
} 
receiving any form of humanitarian status fell from 52 to 32 percent (UNHCR 2002, pp.121-2, 124-5). The EU-15 recognition rate for full Convention status was down to only 15 percent in 2001 .

What happens to those who are rejected? In the late 1990s, removals and voluntary departures in major EU destinations were around half the number of claims that were rejected. Some may have simply left ahead of the threat of removal, but it is hard to escape the conclusion that most did not. ${ }^{6}$ Most probably they either went underground or simply remained in a state of limbo because there was no possibility for legal migration elsewhere. It is also possible that the rising rejection rates have deterred some potential asylum seekers from making claims at all, preferring instead to remain underground rather than to risk rejection and removal. This is all the more likely for those with relatively weak claims and in countries where the flourishing underground economy makes it relatively easy to live and work undetected. For these migrants, low wages and uncertain employment in the EU are better than the conditions they would face in their country of origin. Hence, EU asylum policy has become increasingly bound up with the problem of illegal immigration.

\section{Explaining Asylum Applications to the EU}

Two thirds of all asylum applications in the industrialized world are lodged in the 15 countries of the (pre-enlargement) European Union, and the absolute number of applications has risen dramatically over the last three decades. War and oppression may account for much of the rise but other things must matter too. It is often argued that flows of asylum seekers from poor origins to rich destinations are driven by the same economic and demographic fundamentals that determine other migration flows. Such evidence might be interpreted as support for the view that most asylum seekers are 'economic migrants', but we think it has a bigger influence on the number of refugees that become asylum seekers in the West. Even so, it is far from clear that economic variables can

\footnotetext{
${ }^{6}$ An average of 42,340 first instance claims were rejected in the UK over the years 1997-2001, while 23,200 were successful on appeal. Removals and voluntary departures were around 10,000 per annum in the late 1990s, rising to 13,460 in 2001, Thus removals and departures account for only a little over half of the total number rejected. A parliamentary report noted with dismay that the government was unable to offer even a rough estimate of the number of asylum seekers whose claims had been rejected but who nevertheless remained in the country (UK Home Affairs Committee 2003, p. 12.)
} 
account for much of the trend increase in asylum applications. Furthermore, and as we shall see below, there has been a massive tightening in policies aimed at deterring asylum applications. If these policies have been at all effective, then applications should have been falling rather than rising. There must be other, even stronger, forces off-setting the impact of economic variables and policy.

Quantitative studies of the determinants of asylum claims are scarce. Rotte, Vogler and Zimmermann (1997) analyzed applications to Germany from 17 countries in Asia and Africa over the years 1987 to 1995. They found that the level of political terror in the source country was a key factor generating asylum seekers but that improvements in political rights and civil liberties tended to increase the numbers too. Economic incentives and constraints were also found to be important: the bigger the income gap between Germany and the source country, the greater the number of asylum applications; in addition, source country income by itself had a positive effect, suggesting that poverty constraints were important. In the presence of these and other variables they found that the key reforms in German asylum policy, in 1987 and 1993, had large negative effects on the number of asylum applications. Thieleman (2002) analyzed relative movements in asylum applications across 20 OECD countries from 1985 to 1999 to see whether the German policy results could be generalized. His pooled regression indicated that the key destination country variables were the unemployment rate, the existing stock of foreign nationals and the country's reputation for generosity, as reflected by development aid. An index of the toughness of asylum policy had the expected negative effect on applications, but was not found to be very important. ${ }^{7}$

Existing studies focus either on one destination country (which may not be representative) or on the distribution of asylum claims between countries (thereby excluding source country effects and eliminating overall trends). The econometric result

\footnotetext{
${ }^{7}$ There have also been a number of other studies that assess the effects of policy more qualitatively. A report from the Inter-Governmental Consultations on Asylum and Migration (1997, p. 22) concluded that the fall in asylum applications from its peak in 1992 was partly explained by the tightening of policy in a number of countries. More recently, a report commissioned by the UK Home Office found that, with the exception of policies relating to access to the country's territory, there is little evidence that policy has had the desired effects in stemming the flow applications (Zetter et al. 2003). But without using econometric methods it is impossible to isolate the effects of policy from other variables that determine the number of asylum applications, nor is it possible to take account of the endogeneity of asylum policy.
} 
presented in Table 4 overcomes some of these limitations. The dependent variable is the annual number of asylum claims for 1981 to 1999 from three source regions (Africa, Asia or Eastern Europe) and by 14 EU destinations. These flows are explained by variables representing economic forces, violence and oppression in source regions, and asylum policy in EU destinations. The coefficients imply that an increase of one percent in the ratio of source to destination GDP per capita reduces the number of asylum claims by 2.1 percent while an increase in the unemployment rate of the destination country by one percentage point reduces asylum applications by 7.5 percent. A ten percent increasing in the index of source region conflict raises the number of asylum claims by 7.5 percent while a ten percent improvement in the index representing political rights (higher values represent less freedom) reduces asylum claims by 25 percent. Finally, the index of asylum policy (higher values represent tougher policies) confirms the view that more restrictive asylum policy reduces the number of applications.

These results indicate that economic forces, conflict and policy all influence the number of asylum applications, but how do they account for dramatic increase since the early 1980s? Table 5 provides a decomposition of the change in applications to the EU as a whole from the three source regions between 1981 and 1999. Population growth in source regions added about 50,000 to total applications. The impact of economic growth at home, however, was negative: African and Eastern European GDP per capita fell further behind that of the EU, but these effects were overwhelmed by improved economic performance in Asia, so that the net effect was a reduction in claims by 31,300. And because unemployment was higher in most EU countries in 1999 than it was in 1981, this reduced asylum claims by a further 60,000 . Thus, the view that 'economic migration' is the cause of rising asylum applications seems to be untenable. Economic incentives have substantial effects on asylum flows, but they cannot explain the long-term upward trend.

What about conflict and political oppression? The total effect of conflict across all three source regions was to increase applications by a modest 11,600. Although rising conflict contributed an increase of 83,000 to the annual flow between 1981 and 1992, this was largely reversed as the number and intensity of conflicts declined. Improvements in political rights in sending regions served to reduce the number of asylum claims dramatically, especially from Eastern Europe $(-138,500)$. However, the improved 
political conditions that worked to keep Eastern Europeans at home were partially undone by the increased possibilities of exit. Thus the dummy for Eastern Europe, which represents the period from the fall of the Berlin Wall onwards, raised applications by 70,900 per annum after 1989 .

Finally, the effect of the asylum policy index (Figure 6) was to reduce EU asylum applications by 155,300. This index consists of eleven components representing different elements of policy, each of which is a dummy variable taking the value 1 as policy becomes more restrictive. The result is a dramatic confirmation of the deterrent effects of policy but it leaves us with an even bigger puzzle. When the effects of policy are added to those of other variables, they predict a dramatic fall of 269,300 in the number of asylum applications between 1981 and 1999. Yet over the same period the annual flow actually increased by 202,900 .

What lies behind this mysterious upward trend? One possibility is that policy has been far less effective in deterring asylum applications to the $\mathrm{EU}$ as a whole than the country-specific results in Tables 4 and 5 suggest. Rather than deterring asylum applications, the effect of tougher policies has been to deflect them from one EU country to another. If that were true then the large negative policy effect for an individual country would be offset by the deflection effects of tougher policy elsewhere and so the EU-wide impact of policy might evaporate. To test this hypothesis an additional variable for asylum policy in other EU countries (lagged one period) was added to the Table 4 regression. This took a positive sign as the deflection hypothesis would suggest but the coefficient was small and insignificant $(0.04$, ' $t$ ' $=0.5)$. Deflection effects may be present but they are difficult to identify in the data. And even if net policy effects are zero for the $\mathrm{EU}$ as a whole, the overall increase in asylum applications would still remain unexplained.

The most plausible explanation for the underlying trend is that asylum flows have cumulative effects. These are analogous to chain migration effects that are widely observed in studies of migration, but here they operate a little differently. More than half of asylum applicants have arrived in the EU through illegal channels, often with the aid of increasingly dense and efficient networks of people smugglers. Migrant trafficking has grown since the late 1980s as smugglers have become more professional and expert, 
developments that have been coupled with the opening up of a variety of routes through Eastern Europe. ${ }^{8}$ To test for these effects a variable representing the cumulative flow of asylum applicants to the destination from the source region was added to the Table 4 regression. This took a large and significant coefficient $(0.53$, ' $t$ ' $=6.8)$, and in its presence the coefficient on the time trend becomes small and insignificant. Not surprisingly, this effect is very powerful and it implies that every thousand of the cumulative stock of asylum applications generated a further eighty applications each year. This is a larger effect than is typically found in studies of other migration streams and it can account for most of the otherwise unexplained upward trend. ${ }^{9}$ While the interpretation of this 'stock' effect may be open to question, the view that it represents the expansion of networks (legal and illegal) does seem consistent with much of the qualitative literature.

\section{The Development of Asylum Policies in the EU during the 1990s}

The fundamental basis for asylum policy in the EU and elsewhere in the developed world is the Convention Relating to the Status of Refugees, first signed in Geneva in 1951, and the Protocol that followed in $1967 .{ }^{10}$ It has two key provisions. The first (Article 1) is to define a refugee as someone who is outside his or her country of normal residence and who is unable or unwilling to return to it 'owing to a well founded fear of persecution'. The second (Article 33) is that no person who has claimed asylum under the Convention should be forcibly returned to a territory where he or she may be at

\footnotetext{
${ }^{8}$ The process is well illustrated by a comment from an official of the Hungarian Border Guard: "In the beginning, only a few isolated individuals were involved in human trafficking, but as time passed they started cooperating, and step by step the business developed into an international one. Well-planned routes and well-organised groups have evolved, which are no longer coordinated from Hungary. Trafficking can be coordinated either from the destination country or from the migrants' country of origin. This is the result of a natural process of development; market demand and necessity have contributed to the development of certain branches of crime" (International Organization for Migration 2000, p. 196).

${ }^{9}$ Estimates for other migration streams generally suggest that every thousand of the stock generates a little over 20 additional migrants per year (Hatton and Williamson 2002). However, the elasticity of the flow with respect to the stock presented here is similar to that found in other studies (Pedersen et al. 2004).

${ }^{10}$ The Convention, which became effective in 1954, was originally signed by 29 countries. Other countries have since signed bringing the total to 145 in 2004. Among EU-15 countries, the most recent signatories are Portugal (1976) and Spain (1978) and it is now a condition of EU membership. The right to asylum was earlier enshrined in Article 14 of the Universal Declaration of Human Rights (1948) and also in the European Convention for the Protection of Human Rights (1950), which contains a non-refoulement clause. The main provision of the 1967 Protocol was to extend the coverage of the Convention to those displaced from sources outside Europe.
} 
risk of persecution - the so-called principle of non-refoulement. Any asylum claim submitted in a signatory state must be considered under due process irrespective of the whether the applicant entered the country legally or not. Thus the Convention provides access to asylum procedures for an unlimited number of applicants, once having gained access to the territory, irrespective of whether they enter legally or not. ${ }^{11}$

Nevertheless there are a number of ways that individual countries can deter asylum claims: those designed to restrict access to the country's borders by potential asylum seekers; reforms to the procedures under which applications are processed; those measures relating to the outcome of claims; and changes in the treatment of asylum seekers during processing. Measures of toughness in these different dimensions of policy are displayed in Figure 6. These are averages across 14 EU countries of variables that take a value of 0 before and 1 after the introduction of a restrictive measure. The index for 'access' includes two components whereas those reflecting 'procedure', 'outcomes' and 'conditions' each include three components. These are averages of the constituent elements that were used to form the 11-point policy index for the individual EU countries that was used in the Table 4 regression. Across the EU as a whole, all these dimensions of policy show steep increases in restrictiveness particularly in the first half of the 1990s.

The various elements of policy involved differing degrees of coordination between countries. Measures to tighten external border control followed from the relaxation of internal borders under the Schengen Convention (1990) and the Maastricht Treaty (effective 1993). Carrier sanctions were first introduced in the UK and Germany in 1987 and by the late 1990s they had become universal. Visa restrictions were gradually extended and by 1993 the Schengen signatories shared a joint list that included 73 countries, a figure that exceeded 150 by 1998 .

The most important reforms to the processing of asylum applications followed from the 1990 Dublin Convention and the resolutions of a ministerial meeting in London. It was resolved in Dublin that an asylum claim would be dealt with by one state only, specifically the state of first entry. A consensus was developed in London on three further issues. The first was the 'safe third country' concept that allowed member states to refuse

\footnotetext{
${ }^{11}$ The Convention does not guarantee permanent right of residence in a host country except insofar as this is provided by the non-refoulement clause
} 
to consider asylum claims if the applicant had transited through a country deemed 'safe' where he or she could have sought asylum. The second was to determine that 'manifestly unfounded' asylum claims could be summarily rejected without the right of appeal. The third was the designation of 'safe countries of origin' where there is a presumption of no risk of persecution and where an expedited procedure could be used. In 1994 and 1995 the European Council of Ministers produced a series of further recommendations, the most important of which were on readmission agreements. ${ }^{12}$

These recommendations were not binding on member governments but they gradually diffused across the EU. The most notable case was Germany, where the measures introduced in 1993 required an amendment to the constitution (Basic Law), which contains a clause on the right to asylum. Particularly contentious was the adoption of the safe country of origin concept. Similar sets of policies were introduced in most other EU countries between 1991 and 1998 although the toughness and the timing differed. In addition, there were reforms that affected the outcomes of the asylum procedures. These included the speed with which asylum claims are processed (which limits the opportunities for integration into the host community before a decision is reached), and increases in the toughness of deportation policies in the event of an unsuccessful claim. Some countries also moved to limit the granting of humanitarian status to those denied full Convention status.

Finally, various reforms were introduced relating to the treatment of asylum seekers during processing, in particular dispersal and detention, access to welfare benefits and the right to seek employment. During the 1980s a number of countries permitted asylum seekers to work while their applications were being processed but these rights were largely withdrawn during the 1990s (e.g. France in 1991 and Belgium in 1993). A number of countries also restricted access to welfare benefits, substituting in-kind subsistence for cash benefits, often making them available only at designated reception centers. Such measures were often reinforced by the dispersal of asylum seekers to centers outside the major metropolitan centers and by increasingly strict rules on detention.

\footnotetext{
12 These are bilateral agreements with non-member states that allow asylum seekers to be sent back to countries they had transited. They have been heavily criticized for opening the door to serial refoulement.
} 
It is important to stress, however, that while a degree of harmonization developed during the 1990s, most of the recommendations made at inter-governmental conferences and by the EU Council of Ministers were not binding on member governments, at least until the end of the decade. In the absence of a binding EU-wide asylum policy, individual governments responded to mounting pressures, often with a succession of policy packages. Where some led, others followed. To a degree, EU wide initiatives can be seen as attempts to harmonize policies that were developed by individual national governments from the late 1980s onwards. But true international coordination in the sense that policy is set at the international level, rather than percolating upwards from below, did not emerge until the end of the decade.

The capacity to set policy at the EU level stemmed from the 1997 Treaty of Amsterdam and the European Council meeting at Tampere, Finland in 1999. Under the latter, EU ministers reaffirmed that any common EU policy would be based on a 'full and inclusive' application of the Geneva Convention and in particular that the principle of non-refoulement would be honored. Under the former, the European Commission gained the exclusive right to propose legislation starting in 2002 in order to produce a set of harmonized asylum policies by May 1, 2004. ${ }^{13}$ The first stage of the Common European Asylum System involved setting minimum standards in a number of areas. They include determining which state is responsible for considering an application (so-called Dublin II) and setting minimum standards for the reception and treatment of asylum seekers. While these regulations have been agreed upon, those establishing a common definition of refugee status and procedural standards have not.

Much of the rhetoric surrounding the establishment of an EU-wide framework has been about jointly improving the plight of refugees. Although the first stage of the Common European Asylum system is often seen as a process of leveling down rather than up, there are some signs in the opposite direction. Limited steps on 'burden sharing' include the setting up of the European Refugee Fund in 2000, chiefly to help defray the costs of projects for economic integration of refugees and to finance emergency temporary protection measures in the event of a mass influx of refugees. Also, the draft

\footnotetext{
${ }^{13}$ In the jargon of the EU, the Treaty of Amsterdam moved immigration and asylum from the Third Pillar (intergovernmental) to the First Pillar (Community).
} 
directive on the definition of a refugee explicitly includes those who are in fear of persecution by non-state agents. If adopted, this would widen the definition used by France and Germany, which explicitly exclude as refugees those under threat of persecution by agents of the state rather than by, say, rebels or bandits. ${ }^{14}$ But, while some progress has been made, EU-wide measures still fall far short of a thoroughgoing international asylum policy. A key issue now facing the $\mathrm{EU}$ is how the second stage common European and Asylum System should develop.

\section{The Case for International Cooperation}

Throughout the 1990s, international agencies, NGOs and academic observers sympathetic to the plight of refugees and asylum seekers urged the case for international cooperation. They argued that, as a result of the limited degree of coordination, the evolution of policy has been a race to the bottom. ${ }^{15}$ In the absence of truly international policies there is essentially a non-cooperative outcome that settles on the lowest common denominator. In his influential book Gregor Noll (2000) described in detail the mechanics of what he saw as 'the common market of deflection' within the EU. The implication is that individual governments acting alone have sought to protect themselves against floods of asylum seekers by tightening access, toughening their procedures and affording less generous treatment to asylum seekers, thus deflecting them elsewhere. That raises two questions, one empirical and one theoretical. On the empirical side, we have seen that the deterrent effects of policy shifts in the 1990s are substantial, but the deflection effects are uncertain. On the theoretical side the case is yet to be made that a truly international policy would yield 'better' outcomes and it is worth dwelling a little further on whether (and why) this might be the case.

The outcomes of policy must be judged from a welfare point of view, and the welfare in question is that of the citizens of states that control the admission of refugees through their asylum policies. In this respect, a sharp distinction must be drawn between asylum seekers and other (non-refugee) immigrants. Immigration policy is determined by

\footnotetext{
${ }^{14}$ A strict interpretation of that definition would, in principle, rule out many asylum seekers from countries like Somalia where there is effectively no national government, or from countries like Angola and Sri Lanka, where many of the refugees are fleeing from rebel groups in areas outside the control of the government.
} 
the interests of the host population, either by selecting those most likely to make an economic contribution and least likely to be a welfare burden, or by family reunification. By contrast, asylum policy is altruistic: asylum seekers are admitted because of the benefit it brings to them, not to the host society. Strong humanitarian motives for helping others escape persecution are widely reflected in public attitudes towards genuine refugees. ${ }^{16}$ Thus the 'benefit' of refugees to the host country population comes through satisfying these altruistic motives, rather than through direct self-interest. Such benefit accruing to one individual does not preclude the same benefit accruing to others and hence providing a safe haven to refugees may be thought of as analogous to a public good. Furthermore, individuals with these humanitarian motives are likely to gain additional benefit from the knowledge that refugees also find safety in countries other than their own. However there are also costs associated with asylum seekers that fall exclusively on the country to which they apply.

These elements can be captured in a simple model for two (identical) countries. The net benefit from refugees accruing to the citizens of refugee-receiving country 1 can be represented as:

$V_{1}=\left(r_{1}+\lambda r_{2}\right)^{b}-c r_{1}$

where the valuation $V_{1}$ depends on the number that are received in the home country, $r_{1}$, and the number that are accepted abroad, $r_{2}$, minus the host country cost of refugees, $c r_{1}$. The parameter $\lambda<1$ reflects a lower valuation for refugees accommodated abroad while $b$ $<1$ reflects diminishing marginal utility for (or diminishing tolerance of) refugees.

The number of refugees accepted in country 1 depends on overall 'demand' for refugee places, on the generosity of asylum policy, and on deflection effects from policy in country 2 :

\footnotetext{
${ }^{15}$ See for instance Edminster (2000).

${ }^{16}$ An international opinion survey of 1995 shows that, in the developed world, public attitudes towards genuine refugees are much more positive than those towards immigrants and very much more positive than those towards illegal immigrants (Hatton 2004, Table 13; Hatton and Williamson 2004, Ch. 16). In most countries, a majority of respondents responded positively to the question 'refugees who have suffered political oppression should be allowed to stay.' Similar sentiments are revealed in a Dutch survey where
} 
$r_{1}=\gamma_{1} A-\beta \gamma_{2} A$

where $A$ is total refugee demand and $\gamma$ represents the generosity of the country's asylum policy. The parameter $\beta<1$ captures the deflection effect from policy in country 2 on refugees flowing to country 1 . Thus, for a given level of demand, more refugees flow to country 1 the more generous is country 1's policy and the less generous is that of country 2.

Substituting (2) and the identical equation for country 2 into (1) gives country 1's valuation of refugees as:

$V_{1}=\left[\gamma_{1} A(1-\lambda \beta)+\gamma_{2} A(\lambda-\beta)\right]^{b}-c A\left(\gamma_{1}-\beta \gamma_{2}\right)$

The first order condition for maximizing this valuation with respect to $\gamma_{1}$ gives the optimal policy for country 1 , taking country 2 policy as given, as:

$\gamma_{1}=\left[\frac{c}{b}\right]^{\frac{1}{b-1}}[1-\lambda \beta]^{\frac{-b}{b-1}} A^{-1}-\gamma_{2}\left[\frac{\lambda-\beta}{1-\lambda \beta}\right]$

Thus country 1's policy will be tougher ( $\gamma_{1}$ is lower), the higher the cost per refugee, $\mathrm{c}$, and the higher the overall demand for asylum, $A$. But the effect of toughening policy in the other country (a fall in $\gamma_{2}$ ) depends on the sign of $\lambda-\beta$. On the one hand, because people care about refugees in the other country, they might want to accept more if the other country takes fewer. On the other hand, the deflection effect from tougher policy in country 2 will cause country 1 to toughen its policy.

Solving the two identical reaction functions (4) together gives the non cooperative policy setting $\gamma_{\mathrm{n}}=\gamma_{1}=\gamma_{2}$ as:

70 percent of respondents agreed that 'a country like the Netherlands has a strong moral obligation to admit refugees' (Brons et al. 2001). 
$\gamma_{n}=\left[\frac{c}{b}\right]^{\frac{1}{b-1}}[1-\lambda \beta]^{\frac{-1}{b-1}} A^{-1}[1-\lambda \beta+\lambda-\beta]^{-1}$

If instead asylum policy is set jointly to maximize the total valuation from refugees $V_{1}+$ $V_{2}$, the cooperative common policy parameter, $\gamma_{\mathrm{c}}=\gamma_{1}=\gamma_{2}$, will be:

$\gamma_{c}=\left[\frac{c}{b}\right]^{\frac{1}{b-1}}[1-\beta]^{\frac{1}{b-1}} A^{-1}[1-\lambda \beta+\lambda-\beta]^{\frac{-b}{1-b}}$

In both the cooperative and the non-cooperative regimes an increase in demand for refugee status causes toughening of policy. While this is consistent with the empirical evidence (Hatton 2004, Table 7), that evidence cannot not discriminate between the alternative regimes.

What about absolute levels? As compared with the non-cooperative outcome, the humanitarian benefit derived from refugees is higher, and policy is more generous, in the cooperative case. This can be seen by taking the ratio of (6) to (5):

$\frac{\gamma_{c}}{\gamma_{n}}=\left[\frac{1-\lambda \beta+\lambda-\beta}{1-\lambda \beta+\lambda \beta^{2}-\beta}\right]^{\frac{1}{1-b}}$

Since this is greater than one, $\gamma_{\mathrm{c}}>\gamma_{\mathrm{n}}$, so there are gains from cooperation. This is due to the public good spillover rather than to the internalization of deflection effects. Thus for $\beta=0$ and $\lambda>0$, the cooperative outcome produces higher welfare and more generous policy. ${ }^{17}$ By contrast, if there are deflection effects but no public goods spillover, $\beta>0$ and $\lambda=0$, the cooperative and non-cooperative outcomes are the same. Thus the argument that cooperative policy will raise welfare chiefly because it internalizes deflection effects seems to be misplaced.

\footnotetext{
${ }^{17}$ Just to illustrate, in the case where public good spillover is large, say $\lambda=1$, and with $\beta=0$ and $b=0.5$, the ratio $\gamma_{\mathrm{c}} / \gamma_{\mathrm{n}}$ is 4 .
} 
Of course, as the European experience shows it may be hard (or it may take a long time) to reach agreement when there is an imbalance between countries in the level of refugee demand, in processing and support costs, or in tastes for humanitarian action.

Such asymmetries are not considered in this simple model, and including them makes the analysis less tractable and the conclusions less clear-cut. In addition there may be opportunities for strategic game playing by some countries in order to shift the burden to others. Nevertheless the evidence reviewed above does suggest that centrally determined EU policies tend to be rather less restrictive than those of member governments. If so, then shifting the locus of power over asylum policy to supra-national authorities should benefit both the humanitarian-inclined voters in receiving countries and the refugees themselves.

\section{International Solutions}

In recent years there has been a vigorous debate about reforming asylum policies at the international level. The need for international cooperation is stressed on almost all sides of the debate. One view is that the main instrument of policy, the 1951 Geneva Convention, should either be replaced or reformed. Critics point out that the Convention was conceived in conditions very different from those that exist today. It was designed in the aftermath of wartime displacements in Europe and it operated in the shadow of the cold war when asylum seekers were few in number and when escapees from communism were welcomed. The arrival of large numbers of spontaneous migrants who can take advantage of the legal entitlement to enter the asylum process and are protected against refoulement is seen by some to compromise the entire edifice. Since the right to decide who can and who cannot enter is one of the defining features of a nation state, the clash between individuals' rights under the Convention and under national immigration and asylum laws has become all the more acute.

The trend in western countries has been to deny access to the country's territory so that refugees rights under the Convention do not become operative, to toughen up on Convention status determination, to substitute lesser forms of protection, using expedited processes, and to provide less favorable economic rights and conditions. While this may be consistent with the letter of Convention law, it nevertheless undermines its spirit. The 
weakness of the Convention's provision for international cooperation makes it seem all the more redundant in the eyes of some. ${ }^{18}$ This is not principally a failure of the Convention itself but of cooperation within and around it. As one observer (referring to recent Australian experience) puts it, "if we fail to systematize a process of collectivized protection, we invite criticism of refugee law itself. Worse still we invite de facto withdrawal from refugee law" (Hathaway 2001, p. 44).

However compromised and conditional the current refugee regime may seem, it nevertheless puts a floor under what individual countries can do to avoid their obligations under it. In this minimal sense it forces countries to be more generous than they might otherwise be in the absence of the Convention or under alternatives that might be negotiated in its place. In the light of the previous section's argument that host countries acting alone fail to maximize the welfare even of their own citizens, the Convention, despite its loopholes, may still be seen as welfare enhancing. And even under the present pressures it seems unlikely to fall apart. ${ }^{19}$ Ministers of signatory states gathered to mark the fiftieth anniversary of the Convention strongly reaffirmed their commitment to honoring it. The document that emerged from these 'Global Consultations' called for a long series of enhancements, expressed as six goals, one of which was "sharing of burdens and responsibilities more equitably and building of capacities to receive and protect refugees." ${ }^{20}$ Yet, for the most part, these represent good intentions rather than concrete plans for multilateral action.

It seems likely that the best prospects are for cooperation among regional groups of refugee-receiving states that face similar conditions. The European Union is the obvious example. Beyond the immediate harmonization that followed from Amsterdam

\footnotetext{
${ }^{18}$ Article 35 requires only that contracting States cooperate with the UNHCR in its duty of supervising the application of the provisions of the Convention.

${ }^{19}$ As the UK Government (2003, p. 9) candidly states: "The danger here is that a UK or European withdrawal would lead to the collapse of the Convention with developing countries reasoning that they need not tie themselves to obligations that the developed world is not prepared to keep. This would result in increased global flows of refugees with millions of people being left in limbo without protection. Therefore any future withdrawal from the Geneva Convention needs to be coupled with an alternative regime for refugees."

${ }^{20}$ The other five goals were: strengthening implementation of the 1951 Convention and 1967 Protocol; Protecting refugees within broader migration movements; addressing security-related concerns more effectively; redoubling the search for more durable solutions; and meeting the protection needs of refugee women and refugee children (United Nations 2002, p. 13). Details of the global consultations process and associated documents can be found at: http://www.unhcr.ch/cgi-bin/texis/vtx/global-consultations.
} 
and Tampere, the EU is still searching for a more workable policy for the second phase of its common European Asylum System. While the Commission has repeatedly stressed the need to develop a new system that is both comprehensive and humane, so far the focus has remained firmly on measures to control, efficiently process, and deter asylum seekers. Implicit in this is the recognition that expanding the opportunities for asylum seekers will simply lead to larger flows of illegal immigrants, most of whom fail to qualify as refugees but nevertheless remain in the country.

The European Council received two proposals in 2003, one from the UK Government and one from the UNHCR, each mapping out a future European Asylum System. The UK government's scheme concentrated on extra-territorial processing of asylum claims. Asylum seekers arriving in the EU would be transferred to a Regional Protection Area outside the EU (in a transit country or in the region of origin) where their refugee status would be determined (UK Government 2003). Those found to be in genuine need would then either be transferred back to developed countries according to pre-agreed quotas, resettled elsewhere, or would remain until they could be safely repatriated. Aside from the practicalities of such a scheme, the proposal was widely criticized as burden-shifting rather than burden-sharing and it has since been dropped. ${ }^{21}$

The UNHCR's proposal, which has received a more favorable reception, was presented as the 'EU prong' of its wider so-called 'Convention plus' initiative (UNHCR 2003). Under this scheme one or more closed Asylum Processing Centres would be set up within the borders of the EU, to act as community-wide clearing houses to which asylum applicants would be transferred from member states. At these centers, asylum seekers would be held and their claims determined on behalf of member governments by a new European Asylum Agency. Those whose claims are successful would be transferred for settlement in member states according to 'agreed criteria' for burden sharing. Those whose claims are rejected would be returned to their countries of origin through collective action by member states, and the costs of administration would be defrayed by the pooling of resources in a re-launched version of the European Refugee Fund. While such a system would at first deal with only some claims (such as those 
deemed manifestly unfounded) it would progressively take on wider responsibilities for registering and screening applications and it would become increasingly independent of member governments.

There are a number of reservations even about this proposal. One is the legality of transferring asylum claims to be processed extra-territorially, especially if such functions are delegated to an agency that is not itself a responsible government. Another is the question of whether asylum applicants should be kept in mandatory detention at the Asylum Processing Centres, what freedoms they should have, and who would monitor them. There are also serious questions about whether such centers would become magnets for people-smugglers and traffickers, and about how to deal with unsuccessful applicants who, for one reason or another, cannot be returned to their country of origin. Related to these issues, there is the question of how individual countries might be persuaded to allow EU Asylum Processing Centres to be established on their territory. ${ }^{22}$ Perhaps sufficient inducement might be provided to persuade one or more of the new members of the EU to act as hosts to such a centers, which might be located conveniently close to entry points. And although a legal instrument on resettlement within the EU has been suggested, little attention has been given to exactly how successful claimants would be reallocated among member states.

The fact that member states would still be responsible for the resettlement of refugees suggests that the incentives for full cooperation (in the sense discussed above) would be limited. Our proposal would be a scheme that sets a fixed contribution to the European Refugee Fund (say, in proportion to the country's GDP) and a resettlement quota (say, in proportion to its population). For any EU member that took refugees in excess of its quota there would be a per-refugee rebate that would effectively reduce the cost of resettlement at the margin. This would have two advantages. First, reducing the marginal cost of refugees would help to expand refugee numbers towards the fully cooperative level, even in the absence of full cooperation. Second, the number of refugees that a country accepted would be determined by its preferences for refugees and

\footnotetext{
${ }^{21}$ The UK's proposal was critically evaluated by the European Commission (2003) as well as in commentaries by NGO's such as the Refugee Council, Amnesty International, the United States Committee on Refugees and the European Council for Refugees and Exiles.
} 
by the costs of resettling them, rather than simply on the number who happen to apply to that country.

While a system like this might provide the mechanism for efficient burdensharing, there remains the question of whether the system as a whole would be perceived as more generous. On the one hand, centralized processing and greater enforcement of removals might make applying for asylum less attractive to those with weak claims, discouraging them from applying at all. On the other hand, if the processing of applications using an EU-wide standard led to a larger number being accepted for settlement, then according to the results in Table 4, that would add a boost the total number of applications.

\section{Tackling the Problem at Source}

It has been widely suggested that more resources should be devoted to providing aid to refugees closer to home, partly to prevent unwanted onward migration, but more importantly, to alleviate the plight of the vast majority of refugees who are in countries of first asylum in the origin regions. The UNHCR's Convention-plus agenda calls for situation-specific agreements to expand the opportunities for integration into countries of first asylum as well as for resettlement further afield. It also seeks to create better conditions for voluntary repatriation. ${ }^{23}$ While rejecting the idea of Regional Protection Areas that was proposed by the UK government, the UNHCR argues for rehabilitating refugees through cooperation within origin regions--the so-called regional prong. ${ }^{24}$ But it also requires cooperation from the developed world in providing aid packages in order to improve the economic conditions for refugees as well as providing better access to

\footnotetext{
${ }^{22}$ These and other criticisms of the (revised) UNHCR proposal have recently been discussed by the European Union Committee of the UK House of Lords (2004).

${ }^{23}$ Ruud Lubbers, the current UN High Commissioner for Refugees, introduced this approach as the "4R's"- Repatriation, Reintegration, Rehabilitation and Reconstruction. Various documents describing Convention-plus are available at the UNHCR's website; see in particular "Convention Plus at a Glance" which is periodically updated.

${ }^{24}$ Recent history provides some examples. One is the Comprehensive Plan of Action that was adopted in 1989 by countries in Southeast Asia, which provided for a combination of resettlement (predominantly in the United States), repatriation, and integration into the host countries in the region. Another is the International Conference on Central American Refugees, which involved a commitment by seven Central American countries, also in 1989, to recognizing and integrating refugees from conflicts in El Salvador Guatemala and Nicaragua as well as attempts to broker reconciliation and development (ECRE and USCR 2003, pp. 33-38).
} 
refugee status determination procedures and more generous quotas for resettlement in the West.

If these enhanced procedures involved liberalizing refugee status determination to something approaching that of the developed world, then more would qualify. Given that 80 percent of refugees do not currently have access to these procedures as they operate in the industrialized world, this would lead to a vast increase in the number who would be eligible for resettlement. That number is likely to far exceed the willingness of western countries to accept more refugees, however genuine they may be. It would also provide serious challenges to the neighbors of war-affected countries. One is that by providing superior access to asylum processes and perhaps higher living standards than are available in existing refugee camps, they would act as magnets to greater numbers of displaced persons, who may be less willing to return. Although the UNHCR proposes expanding the opportunities for permanent integration of refugees in countries within the region where they were displaced, many such countries are already hosting far larger numbers than they can (or wish to) absorb. While enhanced development aid tied to local resettlement and integration of refugees might help, those inducements would have to be provided (and policed) on a scale that would go far beyond existing aid budgets.

Policies that significantly improve access to asylum procedures and that enhance the opportunities for resettlement would undoubtedly benefit asylum seekers, especially those from the poorest countries of the Third World. But the incentives they provide are likely also to generate even greater cross-border migration from war torn countries as well as increased pressure for onward migration. As part of its 'three pronged' approach to reforming the refugee regime, the UNHCR lays stress on promoting the voluntary return, reintegration and rehabilitation of refugees in countries of origin. But widening the options for exit and improving the conditions for those who gain access to it (the second prong) would make it all the harder to foster voluntary return and reintegration. Not surprisingly much lip service is paid to targeting development aid to countries in post-civil war situations, not only to ensure a more stable future, but also to make return migration more attractive.

While improving the conditions in source countries seems like the best of all solutions, it is the least well worked out. One issue is whether to devote resources directly 
to repatriation and reintegration programs, or simply to provide some form of economic incentive to return. Some observers argue that such packages should simply be part of broader strategies aimed at improving economic conditions generally. While these might help to foster cross-border remigration from the refugee camps in neighboring regions, they are less likely to stem the flow of long-distance illegal migrants, once such flows have become established. Although relative incomes matter in determining the flows of asylum seekers to the West, it would require dramatic increases in living standards at the source to seriously reduce the numbers. And even that may be too optimistic. Recent studies have suggested that, in the poorest countries, an increase in domestic living standards has conflicting effects on the pressure to emigrate (Hatton and Williamson 2002). While higher income at home may make emigration less attractive, it also makes emigration more feasible by easing poverty constraints.

The best option by far is to find ways of preventing civil wars or to stop them recurring. As we have seen, apart from the upheavals in Eastern Europe and the former Soviet Union, there are positive signs that the ending of the Cold War and the proxy wars associated with it has been associated with a decline in global conflict. Recent interventions in Sierra Leone and Liberia suggest that it is possible for western governments to help promote the settlement of conflicts in the Third World. But the greater challenge is to prevent such conflicts in the first place.

Recent analysis of civil wars suggest that the causes are chiefly economic rather than political (Collier and Hoeffler 1998, 2004). If so, then political interventions that do not get to the root causes are less likely to be successful. In these studies the major causes of civil war are found to be low incomes, dependence on primary commodities, and the dominance of a single ethnic group. One further factor is that the diaspora from the source country, living in the developed world, raises the probability that war will recur. This is because diasporas are often former refugees from displaced minorities who have a vested interest in supplying economic aid to their particular faction. Thus refugees, originally the consequence of war, may become a reason for its persistence.

This suggests a further reason why encouraging the return and reintegration of former refugees is an important priority. Those who return are more likely to have an interest in fostering peace than those who have gained a permanent foothold abroad. But 
the tools for promoting the successful reintegration of refugees in ways that also reduce the risk of war are the least well developed of all refugee policies.

\section{Conclusions}

European governments have reacted to the rising numbers of asylum seekers by introducing successive reforms in their policies in order to deter them. While these have had effects in the desired direction, they have been outpaced by the powerful cumulative forces that have kept up the flow of applications. Two things follow. First, had some of those policies been put in place a decade earlier, the numbers might not have increased so dramatically and the cumulative rise in asylum seeking would have been attenuated. As a result, there would have been less need for ever more draconian measures in the face of the growing pressure of numbers. Second, the numbers are still 'too high' for countries that face strong political pressures to limit them. This may help explain why the transfer of asylum policy from the individual country level to the EU level has not so far resulted in the more generous policies that the theory suggests should result from genuine international cooperation.

In recent years there has been a vigorous debate about the reform of asylum policies and refugee policies on an international scale. Given that existing asylum seeker flows probably exceed those that would be optimal even under more cooperative policies, a radical relaxation of asylum policies seems unlikely. Furthermore, proposals to shift asylum claim processing to reception centers in the regions of origin are also likely to meet with limited success. The resources put into such schemes might be better invested in efforts to help displaced populations when they return home and to create conditions that make civil wars less likely. 


\section{References}

Azam, J-P. and Hoeffler, A. (2002), "Violence Against Citizens in Civil Wars: Looting or Terror?" Journal of Peace Research, 7, pp. 461-485.

Böcker, A. and Havinga, T. (1997), Asylum Migration to the European Union: Patterns of Origin and Destination, Luxembourg: Office for Official Publications of the European Communities.

Brons, M., Meijnen, K. and Schaap, M. C. (2001), "Public Perceptions about Refugees, Asylum Seekers and Persons with Temporary Protection Status: Country Report: The Netherlands," The Hague: International Organisation for Migration.

Collier, P. (1999), "On the Economic Consequences of Civil War," Oxford Economic Papers, 51, pp. 168-183.

Collier, P. and Hoeffler, A. (1998), "On the Economic Consequences of Civil War," Oxford Economic Papers, 50, pp 563-573.

Collier, P. and Hoeffler, A. (2004), The Challenge of Reducing the Global Incidence of Civil War," Oxford University: Copenhagen Consensus Challenge Paper.

Crisp, (1999), "Who Has Counted the Refugees? UNHCR and the Politics of Numbers," Geneva: UNHCR Working Paper No. 12.

Dolan, C. (1999), "Repatriation from South Africa to Mozambique-Undermining Durable Solutions? In R. Black and K. Koser (eds.) The End of the Refugee Cycle? Refugee Repatriation and Reconstruction, Berghan Books: New York.

Edminster, S. (2001), "The High Road or the Low Road: The Way Forward to Asylum Harmonisation in the European Union," USCR World Refugee Survey, 2000, pp.54-61.

European Commission (2003), "Towards More Accessible, Equitable and Managed Asylum Systems," Brussels: Commission of the European Communities.

Gurr, T. R., Marshall, M. G. and Khosla, D. (2001), Peace and Conflict, 2001, University of Maryland: Center for International Development and Conflict Management.

Hathaway, J. (2002) "Refugee Law is not Immigration Law," World Refugee Survey, 2002, New York: US Committee for Refugees.

Hatton, T. J. (2004) “Seeking Asylum in Europe," Economic Policy, 38, pp. 5-62.

Hatton, T. J. and Williamson, J. G. (2002), "What Fundamentals Drive World Migration?” NBER Working Paper 9159, National Bureau of Economic Research, Cambridge, Mass.

Hatton, T. J. and Williamson, J. G. (2003), "Demographic and Economic Pressure on Migration Out of Africa," Scandinavian Journal of Economics, 105, pp. 465-486.

Hatton T. J. and Williamson, J. G. (2004), World Mass Migration: Two Centuries of Policy and Performance (ongoing).

IGC (1997), Report on Asylum Procedures, Geneva: Secretariat of the InterGovernmental Consultations on Asylum, Refugee and Migration Policies in Europe, North America and Australia.

International Organisation for Migration (2000), Migrant Trafficking and Human Smuggling in Europe, Geneva: United Nations.

Koser, K. and Pinkerton, C. (2002), "The Social Networks of Asylum Seekers and the Dissemination of Information about Countries of Asylum," London: UK Home 
Office.

Marshall, M. G. (1999), Third World War: System, Process and Conflict Dynamics, Boulder CO: Rowman and Littlefield.

Marshall, M G. (2002), "Measuring the Societal Impact of War," in F. O. Hampson and D. M. Malone (eds.), From Reaction to Conflict Prevention: Opportunities for the UN System, Lynne Reinner: Boulder, Col.

Morrison, J. and Crosland, B. (2001), "The Trafficking and Smuggling of Refugees: The End Game in European Asylum Policy?” UNHCR Working Paper No. 39, Geneva: UNHCR.

Noll, G. (2000), Negotiating Asylum: The EU Acquis, Extraterritorial Protection and the Common Market of Deflection, The Hague: Martinus Nijhoff.

Pederson, P. J., Pytlikova, M. and Smith, N. (2004), "Selection or Network Effects? Migration Flows into 27 OECD countries, 1990-2000,” Bonn: IZA Discussion Paper No. 1104.

Poe, S. C., Tate, C. N. and Keith, L. C. (1999), "Repression of the Human Right to Personal Integrity Revisited: A Global Cross-National Study Covering the Years 1976-1993.," International Studies Quarterly, 43, pp. 291-313.

Pottenbaum, D. and Kanbur, R, (2001), "Civil War, Public Goods and the Social Wealth of Nations," Cornell University: unpublished paper.

Robinson, V. and Segrott, J. (2002), "Understanding the Decision-Making of Asylum Seekers," Home Office Research Study 243, London: UK Home Office.

Rogge, J. R. (1994), "Repatriation of Refugees," in T. Allen and H. Morsink (eds.), When Refugees go Home, London: Africa World Press.

Rotte, R., Vogler, M. and Zimmermann, K. (1997), "South-North Refugee Migration: Lessons for Development Co-operation," Review of Development Economics, 1, pp. 99-115.

Schmeidl, S. (1997), "Exploring the Causes of Force Migration: A Pooled Time-Series Analysis, 1971-1990," Social Science Quarterly, 78, pp. 284-308.

Thielemann, E. R. (2003), "Why EU Policy Harmonisation Undermines Burden Sharing," Canberra: National Europe Centre Paper 101, Australian National University.

UK Home Affairs Committee (2003), Asylum Removals, Volume I: Report and Proceedings of the Committee, London: House of Commons.

UK House of Lords, European Union Committee (2004), Handling EU Asylum Claims: New Approaches Examined, $11^{\text {th }}$ Report of Session 2003-04, London: Stationery Office.

UK Government (2003), "New International Approaches to Asylum Processing and Protection," accessed as "New Vision for Refugees" from ProAsyl website: http://www.proasyl.de/texte/europe/union/2003/UK_NewVision.pdf

United Nations (2002), Agenda for Protection, New York: ŪN General Assembly $53^{\text {rd }}$ Session.

United Nations (2003), World Population Prospects: the 2002 Revision, New York: United Nations.

United Nations High Commission for Refugees (2001) The State of the World's Refugees: Fifty Years of Humanitarian Action, Geneva: UNHCR.

United Nations High Commissioner for Refugees (2002), Statistical Yearbook, 2001, 
Geneva: UNHCR.

United Nations High Commissioner for Refugees (2003), "Summary of UNHCR

Proposals to Complement National Asylum Systems through new Multilateral Approaches," from Statewatch website at: http://www.statewatch.org/news/2003/jun/unhcr.pdf.

United States Committee for Refugees (2003), World Refugee Survey 2003, New York: USCR.

United States Committee for Refugees and European Council on Refugees and Exiles (2003), Responding to the Asylum and Access Challenge, New York: USCR and ECRE.

Weiner, M. (1997), "Bad Neighbours, Bad Neighbourhoods: An Enquiry into the Causes of Refugee Flows, 1969-1992," in R. Münz and M. Weiner (eds.), Migrants, Refugees and Foreign Policy: US and German Policies towards Countries of Origin, Oxford: Berghahn Books.

Zetter, R., Griffiths, D., Ferretti, S. and Pearl, M. (2003), "An Assessment of the Impact of Asylum Policies in Europe, 1990-2000,” Home Office Online Report 17/03, http://www.homeoffice.gov.uk/rds/horspubs1.html. 
Table 1

Refugees by Region of Origin and Location, 1992 and 2001

(Thousands)

\begin{tabular}{lrrrr}
\hline Region & Refugees by & Origin & \multicolumn{2}{c}{ Refugees by Location } \\
\hline & $\mathbf{1 9 9 2}$ & $\mathbf{2 0 0 1}$ & $\mathbf{1 9 9 2}$ & $\mathbf{2 0 0 1}$ \\
Great Lakes Region of Africa & 700.2 & 1055.3 & 983.6 & 1190.7 \\
West and Central Africa & 960.1 & 540.4 & 950.5 & 570.1 \\
East and Horn of Africa & 1928.8 & 1364.7 & 1784.7 & 966.8 \\
Southern Africa & 1757.3 & 473.6 & 1506.0 & 365.4 \\
North Africa & 245.5 & 206.7 & 257.2 & 183.6 \\
The Middle East & 1454.4 & 901.4 & 266.3 & 463.4 \\
South West Asia & 4682.0 & 3914.4 & 5840.0 & 4066.8 \\
Central Asia & 60.0 & 63.4 & 3.0 & 97.8 \\
South Asia & 503.6 & 396.6 & 579.0 & 322.7 \\
East Asia and the Pacific & 731.6 & 667.4 & 473.0 & 616.1 \\
Eastern Europe & 708.8 & 372.9 & 546.0 & 294.3 \\
South Eastern Europe & 700.5 & 897.2 & 954.4 & 459.6 \\
Central Europe and the Baltic States & 60.1 & 62.8 & 147.8 & 18.7 \\
Western Europe & 0.0 & 1.8 & 1841.0 & 1731.5 \\
North America and the Caribbean & 23.8 & 26.7 & 769.7 & 646.1 \\
Central America & 129.1 & 30.9 & 853.4 & 25.8 \\
South America & 19.4 & 27.9 & 22.1 & 10.5 \\
Stateless/Other/Unknown & 3132.0 & 1025.7 & 20.7 & -- \\
Total & 17798.5 & 12029.9 & 17798.5 & 12029.9 \\
\hline
\end{tabular}

Source: UNHCR (2002: 84, 88). 
Table 2

Top 20 Sources and Destinations of Asylum Seekers 1982-2001

\begin{tabular}{|c|c|c|c|c|c|c|c|c|c|}
\hline \multirow[t]{2}{*}{ Source Country } & \multicolumn{2}{|c|}{ 1992-2001 } & \multicolumn{2}{|c|}{ 1982-1991 } & \multirow[t]{2}{*}{ Destination Country } & \multicolumn{2}{|c|}{ 1992-2001 } & \multicolumn{2}{|c|}{ 1982-1991 } \\
\hline & No. & $\begin{array}{l}\text { per } \\
1000\end{array}$ & No. & $\begin{array}{l}\text { per } \\
1000\end{array}$ & & No. & $\begin{array}{l}\text { per } \\
1000\end{array}$ & No. & $\begin{array}{l}\text { per } \\
1000\end{array}$ \\
\hline Yugoslavia FR & 817.2 & 77.5 & 269.8 & 17.0 & Germany & 1597.3 & 19.6 & 996.9 & 1.7 \\
\hline Iraq & 310.8 & 15.4 & 52.1 & 3.4 & United States & 869.0 & 3.2 & 437.7 & 0.2 \\
\hline Turkey & 308.8 & 4.9 & 499.3 & 9.6 & United Kingdom & 576.6 & 10.0 & 164.5 & 0.3 \\
\hline Romania & 304.7 & 13.1 & 195.4 & 8.6 & Netherlands & 358.6 & 23.2 & 95.0 & 0.7 \\
\hline Afghanistan & 204.1 & 10.6 & 54.0 & 4.0 & Canada & 286.3 & 9.8 & 239.4 & 0.9 \\
\hline El Salvador & 196.5 & 34.7 & 69.6 & 14.6 & France & 281.0 & 4.8 & 347.4 & 0.6 \\
\hline Bosnia and Herzegovina & 186.1 & 54.4 & -- & -- & Switzerland & 243.5 & 34.2 & 170.2 & 2.6 \\
\hline Sri Lanka & 168.9 & 9.5 & 176.8 & 11.3 & Sweden & 228.6 & 25.9 & 183.2 & 2.2 \\
\hline Islamic Rep. of Iran & 161.1 & 2.6 & 195.5 & 4.0 & Belgium & 219.5 & 21.7 & 69.7 & 0.7 \\
\hline Guatemala & 154.8 & 15.5 & 38.1 & 4.9 & Austria & 128.0 & 15.9 & 134.0 & 1.8 \\
\hline China & 149.7 & 0.1 & 21.9 & 0.0 & Denmark & 97.4 & 18.6 & 45.3 & 0.9 \\
\hline Somalia & 147.6 & 20.1 & 51.1 & 7.7 & Australia & 89.2 & 4.9 & 30.1 & 0.2 \\
\hline India & 124.4 & 0.1 & 63.2 & 0.1 & Spain & 84.2 & 2.1 & 37.5 & 0.1 \\
\hline Pakistan & 113.2 & 0.9 & 67.9 & 0.7 & Italy & 83.4 & 1.5 & 55.0 & 0.1 \\
\hline Russian Federation & 105.2 & 0.7 & 25.0 & 0.2 & Norway & 71.1 & 16.3 & 32.3 & 0.8 \\
\hline Dem. Rep. of Congo & 103.9 & 2.3 & 97.5 & 3.0 & Turkey & 54.5 & 0.9 & 27.8 & 0.1 \\
\hline Algeria & 92.6 & 3.3 & -- & -- & Czech Republic & 48.1 & 4.7 & 3.8 & 0.0 \\
\hline Bulgaria & 91.2 & 10.8 & 47.5 & 5.3 & Ireland & 39.7 & 11.0 & 0.03 & 0.0 \\
\hline Nigeria & 77.1 & 0.8 & 33.0 & 0.4 & Hungary & 37.5 & 3.7 & 4.4 & 0.0 \\
\hline Mexico & 74.5 & 0.8 & -- & -- & Poland & 25.0 & 0.6 & 2.4 & 0.0 \\
\hline
\end{tabular}

Source: Asylum seeker numbers from UNHCR (2002: 112-3, 115-6); Population totals for 1995 and 1985 from United Nations (2003: various tables). 
Table 3 Explaining Refugee Displacements in Africa.

$$
\begin{aligned}
\text { Refs } / \text { Pop }= & -32.4+35.7 \text { Coups }+ \\
& (4.8) \quad(1.9) \\
& +35.4 \text { Deaths, } \quad \text { Crises }+25.2 \text { GuerWar }+35.4 \text { CivWar } \\
& \text { Pseudo- } \mathrm{R}^{2}=0.07, \text { Log Likelihood }=-595.6
\end{aligned}
$$

Note: $\mathrm{t}$ statistics in parentheses.

Sample: Balanced panel of 41 countries in Sub-Saharan Africa by 6 years (1987-92).

Variable Definitions: Refs/Pop: number of refugees per thousand of source country population; Coups: dummy $=1$ for years when there was a political coup d'etat; Crises: dummy $=1$ for years of government crisis; GuerWar; dummy $=1$ for years of guerilla warfare; CivWar: dummy $=1$ for years of civil war; Deaths: number of military deaths in civil war per thousand of the population.

Method: Tobit regression on 246 country/year observations.

Source: Hatton and Williamson (2003), Table 2 where the data are discussed in more detail. The original source for most of the variables is Robert Bates' Africa project, available at http://africa.gov.harvard.edu//.

\section{Table 4: Explaining Asylum Applications to the EU}

$$
\begin{aligned}
\text { Log Apps/Pop }= & -2.12 \log \text { GDPRatio }-7.47 \text { UDest }+17.17 \text { Conflict }+0.51 \text { PolRights } \\
& (4.4) \\
+ & 0.26 \operatorname{logStock} 81+0.77 \text { EastEur90 }-0.09 \text { Policy }+0.20 \text { Time } \\
& (5.8) \quad(1.9) \\
& \mathrm{R}^{2}=0.78 ; \quad \text { No. Obs. }=798
\end{aligned}
$$

Note: ' $\mathrm{t}$ ' statistics in parentheses calculated from robust standard errors.

Sample: Annual data for three source regions, Africa Asia and Eastern Europe by 14 EU destination countries (EU-15 excluding Luxembourg), for 1981 to 1999.

Variable Definitions: Apps/Pop: asylum applications from source region to destination country/ source region population (millions); LogGDPRatio: log ratio of GDP per capita, source region to destination country; UDest: unemployment rate in destination country; Conflict = index of the scale and intensity of conflict in source region; PolRights: Freedom house index of political rights in source region; LogStock81: log population from source region living in destination country in 1981/source region population; EastEur90: dummy =1 for Eastern European source from 1990; Policy: index of toughness of asylum policy in destination country.

Method: Instrumental variables; Policy instrumented. Fixed effects for three source regions and 14 destination countries and dummy for Italy from 1990 (for Asia and Africa only) included but not reported. Source: Hatton (2004), Table 8; see also the Appendix for details of the data sources. 
Table 5

Decomposition of Change in Asylum Applications by Source Region, 1981-99

(Thousands)

\begin{tabular}{|c|c|c|c|c|}
\hline & Africa & Asia & E. Europe & Total \\
\hline Source region population & 18.1 & 28.6 & 2.7 & 49.4 \\
\hline GDP per capita ratio & 30.1 & -79.1 & 17.7 & -31.3 \\
\hline Unemployment in destination & -7.7 & -28.6 & -23.6 & -59.9 \\
\hline Conflict index & -11.7 & -28.3 & 51.3 & 11.3 \\
\hline Political rights index & -14.2 & -11.6 & -138.5 & -164.2 \\
\hline Eastern Europe from 1989 & -- & -- & 70.9 & 70.9 \\
\hline Asylum Policy & -25.5 & -66.4 & -63.4 & -155.3 \\
\hline Total above effects & -10.9 & -175.6 & -82.8 & -269.3 \\
\hline Actual change, 1981-99 & 53.0 & 80.4 & 69.5 & 202.9 \\
\hline
\end{tabular}

Source: Hatton (2004: Table 10). 
Figure 1

Worldwide Stock of Refugees

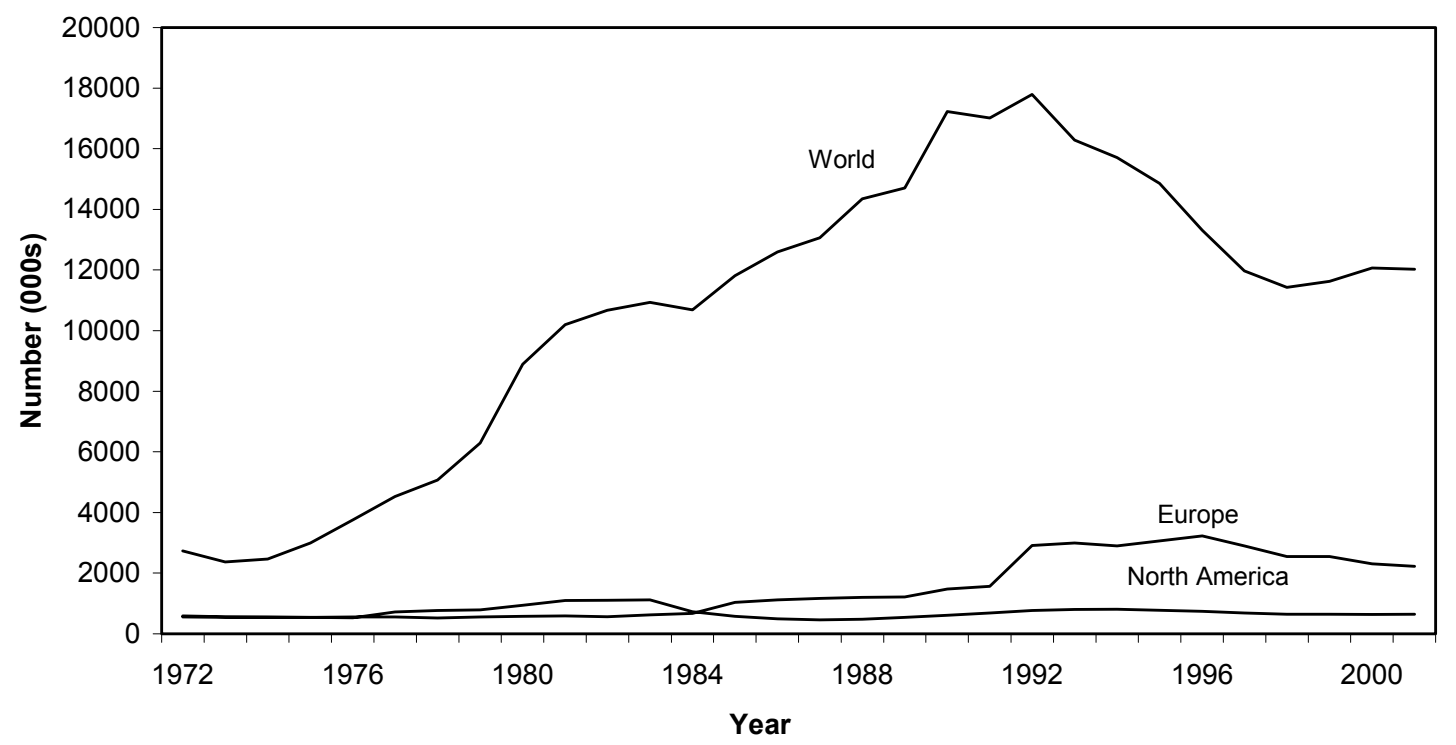

Source: UNHCR (2001: Annex 3).

Figure 2

Asylum Applications to Industrialized Countries, 1982-2001

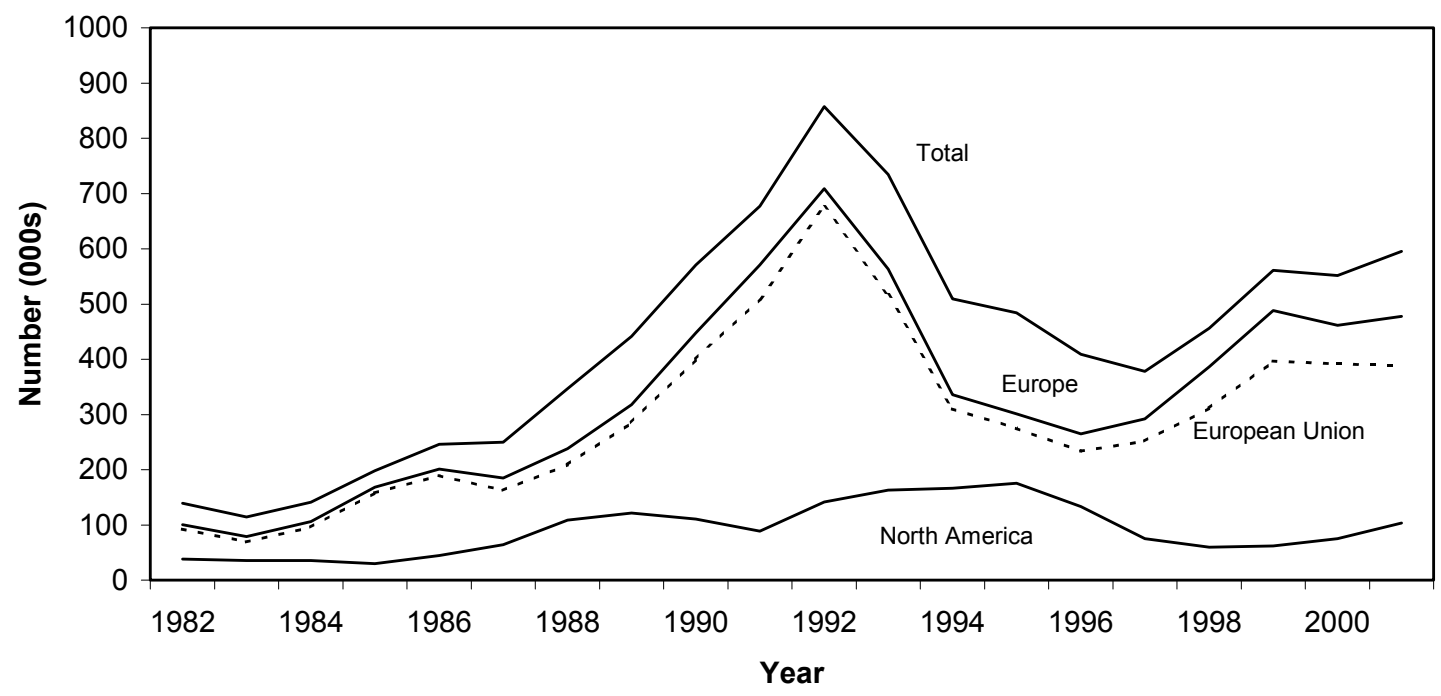

Source: UNHCR (2002: 113-114). 
Figure 3

Asylum Applications by Source Region, 1982-2001

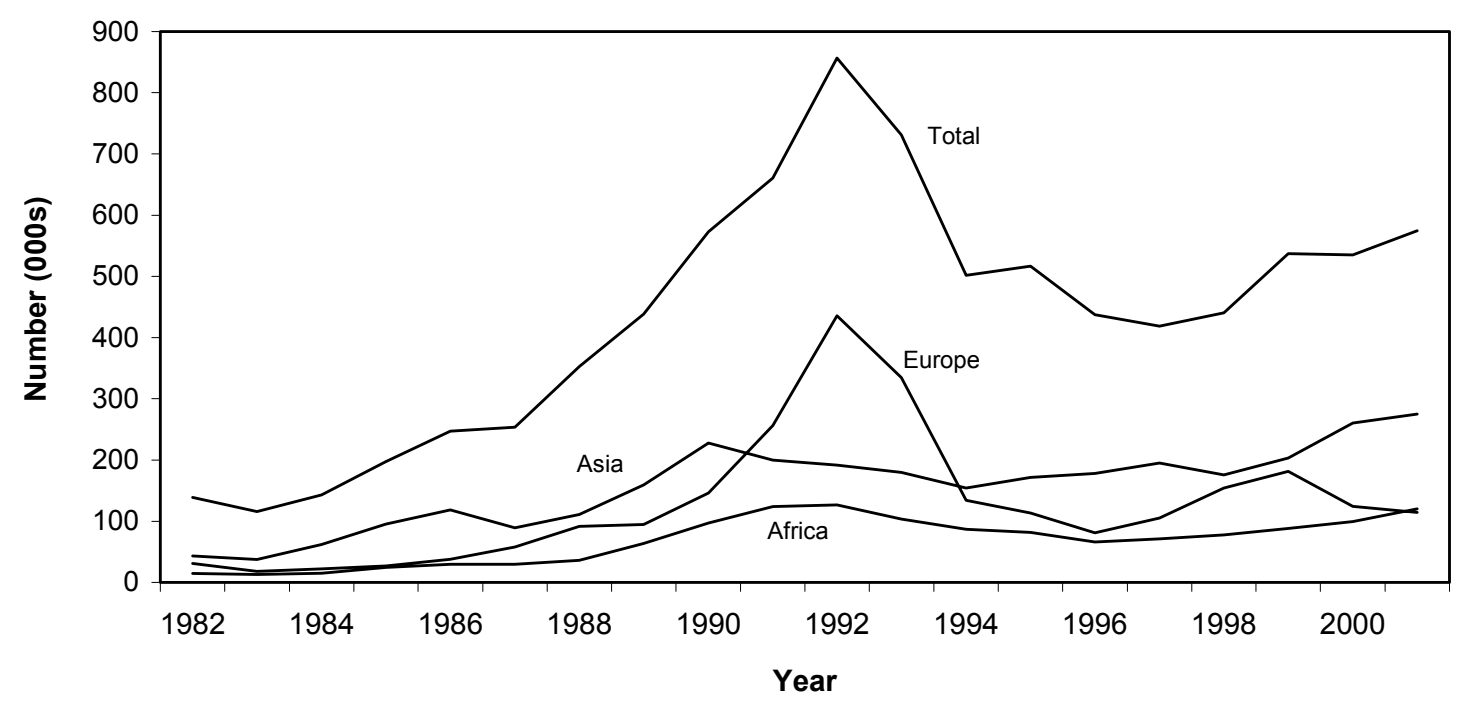

Source: Data kindly provided by Monty Marshall.

Figure 4

Global Warfare Index

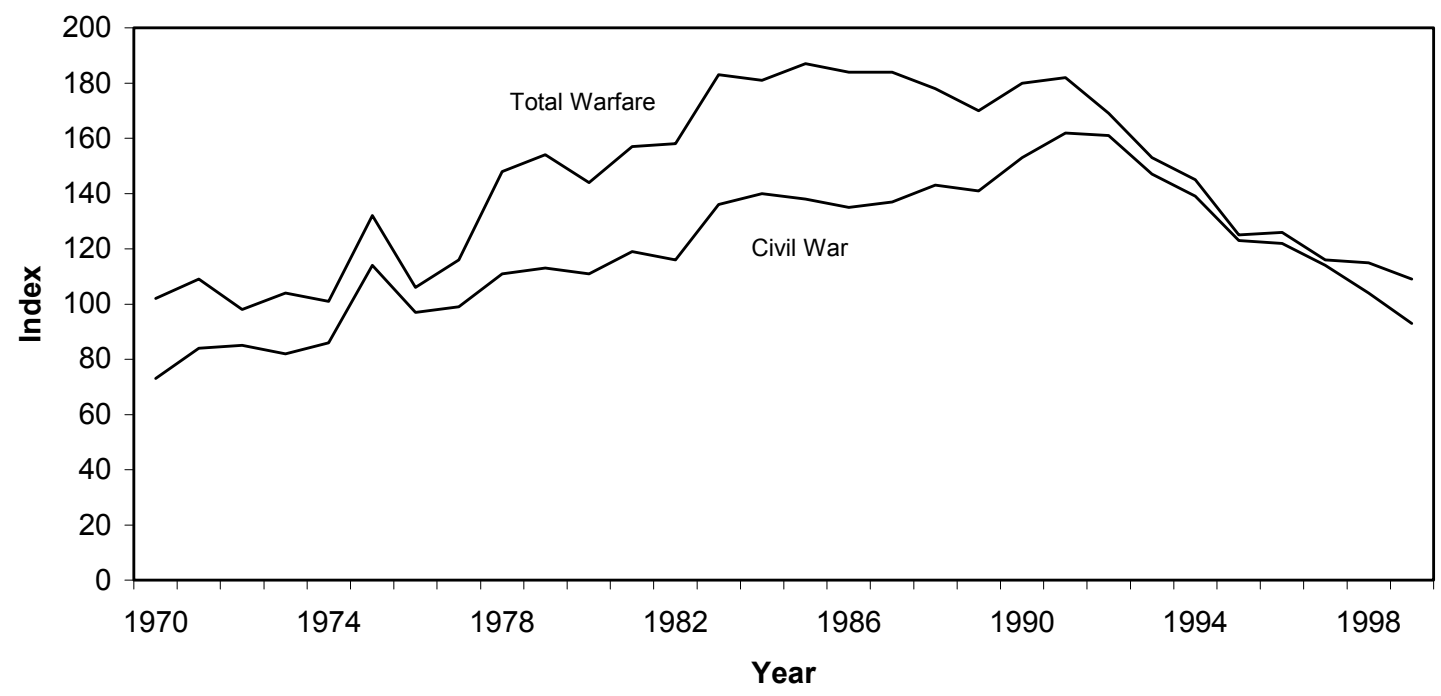

Source: Hatton (2004). 
Figure 5

World (Un)Freedom Index, 1975-6 to $1999-2000$

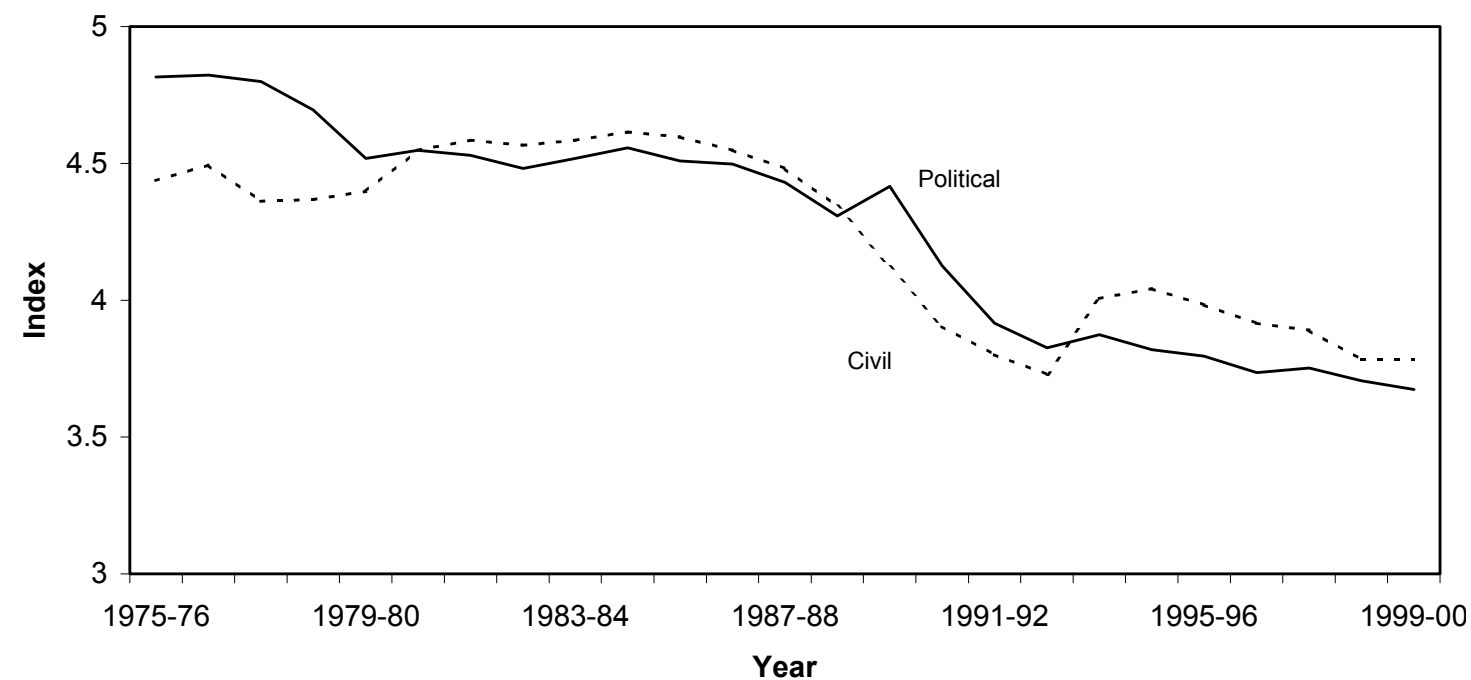

Source: Hatton (2004)

Figure 6

Asylum Policy Index, EU Average, 1980-99

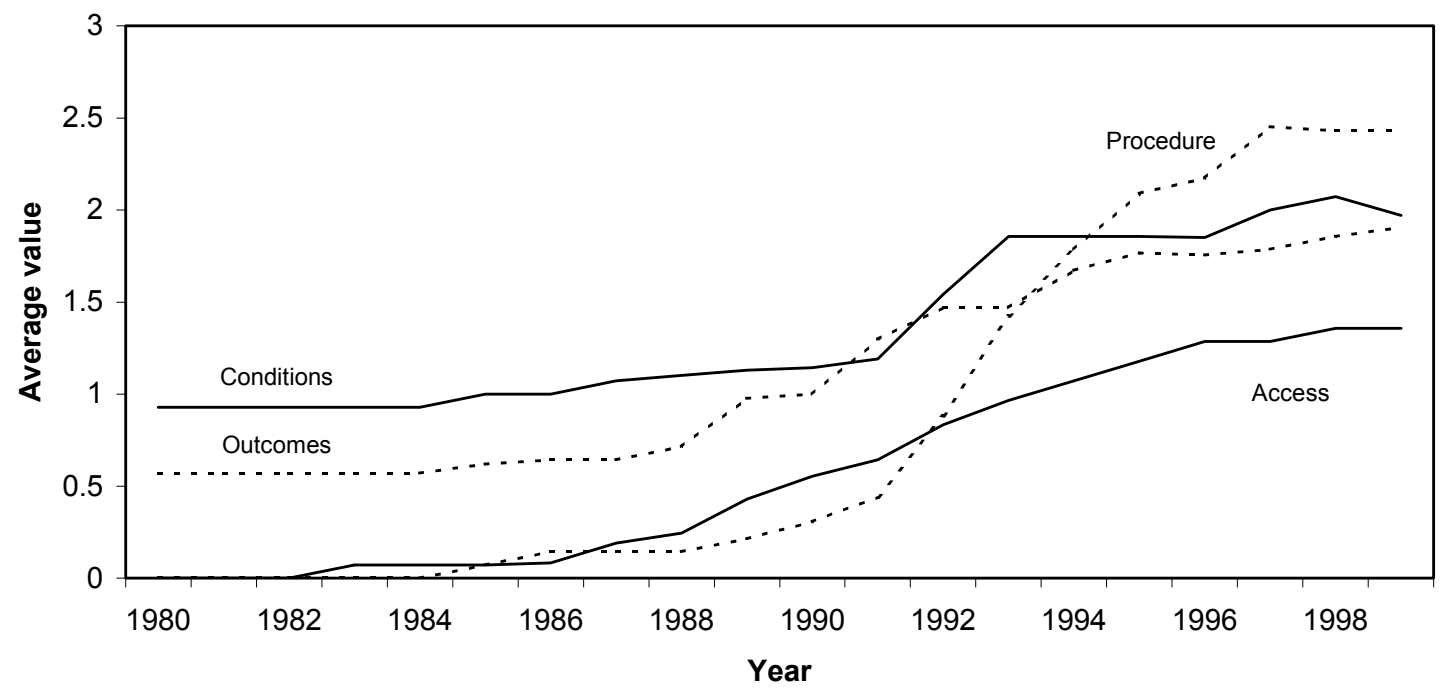

Source: Hatton (2004) 